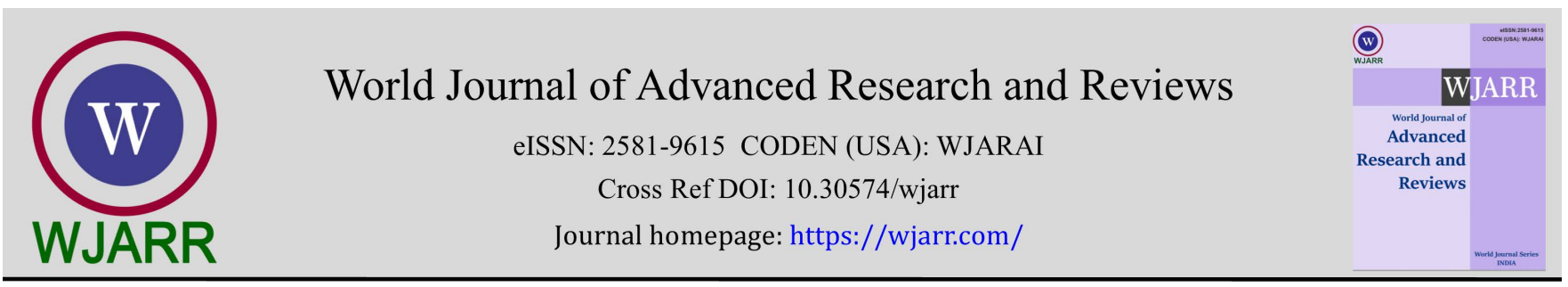

(RESEARCH ARTICLE)

\title{
Labor transformation performance in Southern Sumatra, Indonesia
}

\author{
Amri Amir * and Zulgani Zulgani \\ Faculty of Economics and Business, Universitas Jambi, Indonesia.
}

World Journal of Advanced Research and Reviews, 2021, 09(01), 268-280

Publication history: Received on 15 January 2021; revised on 23 January 2021; accepted on 25 January 2021

Article DOI: https://doi.org/10.30574/wjarr.2021.9.1.0031

\begin{abstract}
This study analyzes the workforce transformation performance and the patterns of change and composition of job opportunities in Southern Sumatra. It will also examine the influence of export variables and domestic investment on employment in the Jambi Province. The results showed that the workforce structure in Southern Sumatra has undergone changes but is still dominated by the primary sector (agriculture and mining), meaning that there has not been a transformation of labor. The analysis shows that exports and domestic investment influence the absorption of work in Southern Sumatra.
\end{abstract}

Keywords: Domestic investment; Export; Workforce transformation.

\section{Introduction}

Southern Sumatra consists of 5 provinces, namely Jambi Province, South Sumatra Province, Bangka Belitung Province, and Lampung Province. The economies of these five provinces are dominated by the agricultural and extraction sectors. These two sectors have contributed significantly to the economic growth of the Southern Sumatra region. In addition to contributing significantly to the formation of Gross Regional Domestic Product (GRDP) and economic development, the agricultural and mining sectors in these areas also contribute to creating job opportunities and expanding job opportunities, both in the short and long term.

The average economic growth in these five provinces in the last 3 (three) years (2013-2015) tended to decline, from 5.99 percent to 4.75 percent per year. Meanwhile, labor absorption during the period 2013 - 2015 increased by an average of 7.3 percent. On the other hand, the growth of domestic investment in 5 provinces in Southern Sumatra in the 2012 - 2016 period increased quite sharply, namely by an average of 59.04 percent. The increase in domestic investment in Bengkulu Province was 106.10 percent, and Lampung increased by 111.01 percent per year on average. Meanwhile, for other provinces, especially Jambi Province and South Sumatra Province, domestic investment growth was only 28.03 percent and 30.63 percent on average.

The main exports in 5 provinces in Southern Sumatra are exports of products derived from agricultural products, especially palm oil and rubber. Therefore agricultural products play an essential role in the Economy in Southern Sumatra. During the 2012 - 2016 period, export activities in 5 provinces in Southern Sumatra experienced a significant decline, ranging from minus 4.05 percent to minus 32.10 percent. Lampung Province experienced a decrease of 4.05 percent, and this figure is the smallest compared to other provinces in Southern Sumatra. Meanwhile, the export growth rate that experienced a sharp decline was Bengkulu Province, amounting to minus 32.10 percent. Likewise, Jambi Province and South Sumatra Province experienced a decrease of respectively 14.80 percent and 19.78 percent.

\footnotetext{
${ }^{*}$ Corresponding author: Amri Amir

Faculty of Economics and Business, Universitas Jambi, Indonessia.

Copyright (C) 2021 Author(s) retain the copyright of this article. This article is published under the terms of the Creative Commons Attribution Liscense 4.0.
} 
Based on the facts mentioned earlier, there is an exciting thing in the Southern Sumatra region: the decline in exports and economic growth, but investment and employment have increased significantly. Therefore, it is interesting to study how the workforce structure and how investment and exports affect work in the Southern Sumatra region.

\subsection{Literature review}

The transformation of the production or economic structure is an essential part of the long-term economic development process. Timmer [1] argues that structural change is defined as part of the process of economic growth, which can be traced from (1) the decline in the contribution of the agricultural sector to Gross Domestic Product (GDP) and the decline in employment opportunities in the agricultural sector, (2) the rapid urbanization process, where residents in rural areas move to urban areas, (3) the growth and development of modern industries and service economies, (4) there is a demographic transition marked by a decrease in the mortality and birth rates.

Chenery, Syrquin and Elkington [2] stated that the critical point of changing economic structure is studying the effects of structural transformation due to economies of scale, because of resources, and because of the scale of domestic demand. Besides that, the aspect of population density plays an important role in trade and development patterns. Pieper [3] argues that economic transformation is a combination of accelerated economic growth, faster export expansion, economic diversification, and structural changes. The shift from a traditional economy to a modern economy is also influenced by capital accumulation, technological changes, and productivity growth. In this process, economic sectors' development is highly dependent on natural resources, such as the manufacturing industry sector, a potential sector, and a business scale to grow and develop faster [4].

Based on these facts, the non-agricultural sector usually grows faster and becomes increasingly important in the transformation process [5]. Goel and Restrepo-Echavaria [6] argue that structural transformation more broadly is the relocation of economic activities to the agricultural sector, the manufacturing industry sector, and services that accompany the process of modern economic growth. Kuznets argues that economic structure changes are a series of interrelated changes in the composition of aggregate demand, foreign trade, aggregate supply needed to support the development process, and sustainable economic growth [7]. Meanwhile, Anwar et al. [8] also argued that various socioeconomic transformation processes usually accompany economic growth and increase national income per capita over a long time.

Chenery, Syrquin and Elkington [2] suggest that economic growth's main engines are changes in economic structures, industrial structures, and institutional economic structures. The transformation occurs from the traditional agricultural sector to the industrial sector and from industry to services. Djojohadikusumo [9] explains that the development process is seen as a transition which over time is marked by multidimensional transformations, namely a transition from a stagnating economic constellation to a state balance that already contains dynamic force movements in its development. The multidimensional transformation includes changes in structure-the economy. Timmer and Akkus [10] state that four main components are interrelated in the process of changing the economic system, including (a) a decrease in the contribution of the agricultural sector to GDP and employment opportunities (b) the growth and development of modern industries followed by The increasingly widespread service economy (c) the development of urbanization, which is indicated by the movement of population from rural areas to urban areas and (d) the occurrence of a demographic transition marked by a decrease in the mortality rate.

Changes in the economic structure that occur in economic development can also be seen from fundamental changes in the financial system from a traditional economy to a more advanced economy based on the advantages of the industrial sector, mainly dominated by the manufacturing industry sector (modern industry) [11]. This change in sectoral composition must also be followed by an increase in economies of scale (return to scale), which is often interpreted as a positive relationship between output growth and productivity growth, which is believed to drive the economic growth process.

An increase in the per capita income of a country/region causes a structural transformation to occur. Amir [12] argues that structural change theory focuses its analysis on the mechanism of changing economic structures in developing countries from traditional agriculture to more modern economies, namely the manufacturing industry and the service economy. In creating a theory of changes in the economic system, Chenery and Syrquin technically divide the economy of a country into four groups, namely: the primary sector, which includes the agricultural sector and the mining sector; The industrial sector, which consists of the manufacturing industry sector and the construction sector; The utility sector consists of the water gas electricity sector, the transportation and communication sector. 
Tsun Se Cheong and Yanrui Wu's research found that industrialization and tertiary industrial development benefit China's economic growth. The labor surplus in the rural sector has been reallocated to the secondary and tertiary sectors. The structural transformation process has improved living standards and quality of life, but China's high economic growth has also been influenced by structural transformation but at the same time. Meanwhile, industrial development (industry upgrading) also increases regional inequality in China.

Mecik and Afsar [13] found a significant impact of transforming the labor market's economic structure. However, on the other hand, the structural transformation also hurt employment opportunities in OECD member countries, as indicated by an increase in unemployment.

Afzal's [14] found that other variables such as agriculture, openness, and financial integration are cointegrating apart from the industry. Exposure affects growth on the one hand, while on the other hand, it increases the international dependence of the Pakistani economy, especially imports. There is a long-term relationship between economic growth and structural transformation as found in the neoclassical model. Trade liberalization is not a recipe for the long term.

World Bank [15] states that Indonesia is still facing difficult challenges in the future. Indonesia's progress is still very dependent on job creation in sectors with low productivity levels. However, in the long term, a shift to economic activities with higher added value in the manufacturing and services sector will be required. In the three main sectors of the Indonesian economy, moving towards an industry with high added value, such as the manufacturing, food processing, and chemical sectors, will encourage job creation. Exports of goods from the manufacturing industry are also supported by the transport, utilities, and financial sectors.

Research by Behera and Tiwari [16] found that the growth positively influences structural transformation in the contribution of sector income outside agriculture, investment outside the agricultural sector, differences in real wages in rural and urban areas. And human capital investment. The transformation of labor from an unorganized sector (traditional sector) to an industry organized (the manufacturing industry sector) is positively influenced by investment and human capital investment and is negatively affected by labor productivity, urban population. The labor-capital ratio in the industry is organized.

The results of Ferede's [10] study concluded that structural transformation is an essential key for sustainable economic growth, increasing labor productivity, and reducing the number of poor people. The development of labor productivity in Ethiopia during the analysis period has increased due to individual sectoral productivity growth, with a relatively small contribution to structural change. Low levels of labor productivity in the agricultural and manufacturing industries.

\subsection{Research Framework}

The transformation of employment opportunities in the regional economy is influenced by the Gross Regional Domestic Product, domestic investment component, and exports. These variables are available components that are theoretically and empirically considered to influence the employment opportunity process in a region. It is in this connection that the researcher develops the following framework.

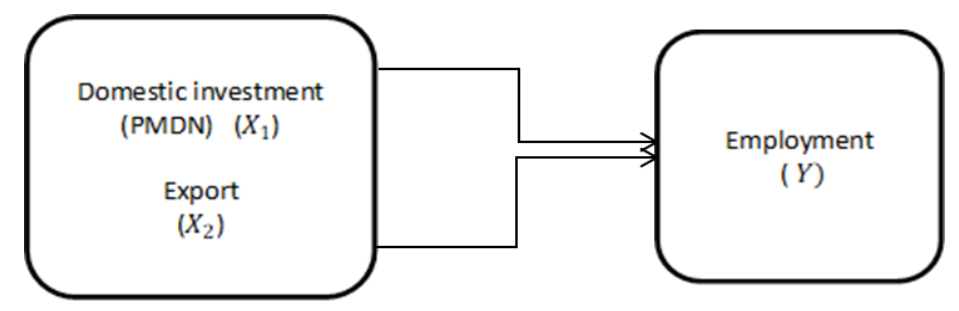

From the framework as stated above, the following hypothesis is formulated: it is assumed that the variables of domestic investment and exports have a positive and significant effect on employment opportunities in the southern part of Sumatra.

\subsubsection{Research methods}

The method used in this research is the quantitative method. The model used for analysis is the result of modification of the models that have been used by previous researchers. The data used in this study mostly consisted of secondary data obtained from several related agencies such as from Bank Indonesia, in particular the publication of Regional Economic Studies (KER), the annual edition of the Indonesian Economic Report, from the National Planning and 
Development Agency (BAPPENAS), the Central Bureau of Statistics. (BPS) concerns GRDP figures, Regional Development in Figures (PDDA), BPS Strategic Data, Indonesian Statistics, and quarterly reports on the Indonesian economy, published regularly by the Central Statistics Agency (BPS).

For data analysis, an approach used with a panel data regression with the following model:

$=\llbracket \beta Y \_i t \rrbracket \_0+\beta \_1$ 『LnX $\_1 i t+\beta \_2 \operatorname{LnX} \_2 i t+\beta \_3 \operatorname{LnX} \_3 i t+\mu_{-}$it

Where:

Y_it = contribution of labor in the primary, secondary and tertiary sectors in each sample province (expressed in percent)

$\beta_{-} 1,2,3=$ regression coefficient for independent variables

$\beta \_0$ constant

X_1 = Gross Regional Domestic Product expressed in billion rupiahs)

X_2 = Domestic investment (expressed in billion rupiah)

X_3 = Exports (expressed in US dollars)

i_ $\quad=$ cross section data (namely 4 provinces in southern Sumatra)

$\mathrm{t}_{-} \quad$ = time series data (observation year from 2010 to 2015)

Three possible approaches can be used, including:

\subsubsection{PLS method}

This PLS approach only uses the standard OLS method wherein the estimation it is assumed that each unit has the same intercept and slope; the model is as follows:

$Y \_$it $=\beta \_0+\beta \_1 X_{-}$it $+\mu \_$it

Furthermore, to estimate the panel data regression equation's parameters above, the OLS method is used.

\subsubsection{FEM approach}

The FEM approach assumes that the intercept between cross-sections is different, but the slope remains the same. The FEM technique uses a dummy variable with a value of 0 indicating no influence, while a value of 1 indicates that there is influence. The basic model is as follows

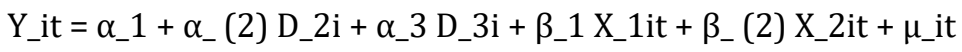

The addition of dummy-relative variables is simple, but it can produce complex estimation results if using more crosssection data.

\subsubsection{REM approach}

This REM method uses an error term approach to see the relationship between cross-sections and time series. This approach tends to see changes between individuals and over time. REM model refinement of FEM approach. The models are as follows:

$Y \_$it $=\beta \_0 i+\beta \_1 X_{-} 1 i t+\beta \_2 X_{-} 2 i t+\mu \_$it

Unlike the FEM model, in the REM model, $\beta_{-} 01$ is no longer considered constant but is positioned as a random variable with the mean value of $\beta \_2$ (without subscript i). 


\subsubsection{Model Selection}

To get the best model, researchers use the Chow test or commonly called the F test, to determine whether the FEM model is better than PLS. Besides, the Hausman test will also be carried out. This approach is used to determine whether the FEM model is better than the REM model. The operational definitions of the variables presented in this study are as follows:

Domestic Investment (PMDN) is the realized value of the domestic investment in each province that is used as the research sample in the span of the observation year, which is stated in billion rupiah.

Export is the province's export value, which is used as the research sample in the span of the observation year, which is expressed in millions of US dollars.

Employment opportunities are the number of workers or labor force who work in 9 sectors in each province that are used as research samples in the span of the observation year, which is stated in people or people.

\section{Results and discussion}

\subsection{Economic growth}

In general, the Southern Sumatra region's economy still relies on the primary sector as an economic growth source. Due to the primary sector as the mainstay sector in Southern Sumatra, the primary sector remains the dominant sector in providing large enough employment opportunities, namely the utility sector, the service sector, the trade sector. It shows how important the primary sector's role is in contributing to the economy Southern Sumatra region. For Jambi Province, in 2013, the primary sector absorbed 54.28 percent of the total working workforce. In 2015, this figure had increased to 54.58 percent.

Meanwhile, in South Sumatra Province, labor absorption in the primary sector was relatively stagnant, namely 56.28 percent in 2013 and 56.29 percent in 2015. In Bengkulu Province, the agricultural sector's absorption to labor increased from 53.35 percent in 2013 to 55.45 percent in 2015. In Lampung Province, there was a tendency to decrease employment in the primary sector, namely from 51.86 percent in 2013 to 49.57 percent in 2015.

The Economy in Southern Sumatra is generally characterized by a homogeneous region that relies on the primary sector (agriculture and mining). The primary sector is the sector that absorbs the largest number of workers, especially for uneducated workers. Apart from the primary sector, the utility sector is a sector that can absorb more labor. Meanwhile, the industrial sector cannot be relied on as a mainstay sector in absorbing the workforce, increasing every year

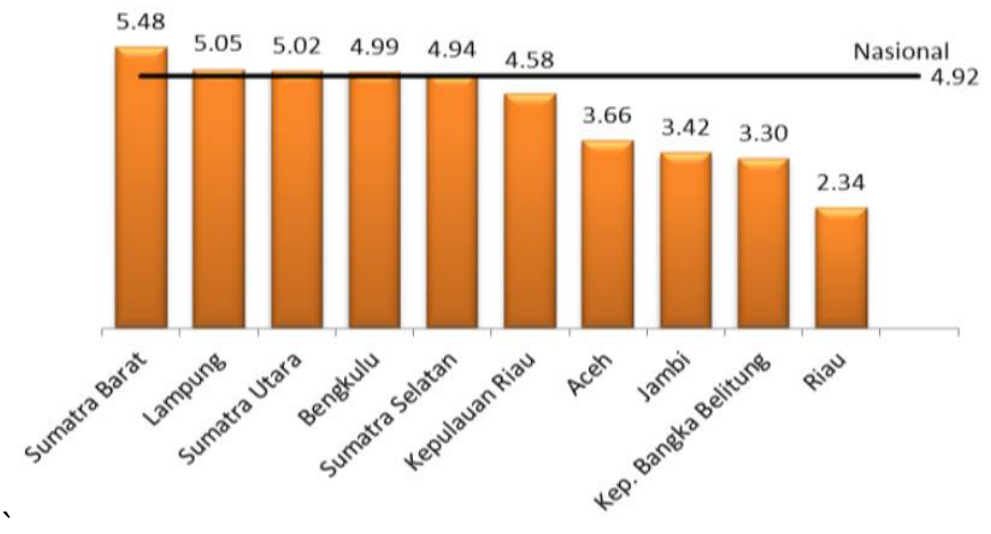

Graph 1 Provincial Economic Growth in Sumatra in 2016.

\subsection{Domestic Investment in Southern Sumatera}

The flow of domestic investment in 5 provinces in Southern Sumatra shows a quite encouraging trend. Domestic investment growth increased quite sharply. Especially in the Provinces of Bengkulu and Lampung, which in the 20122016 period grew by 106.10 percent and 111.01 percent on average per year, while for the other two provinces, Jambi and South Sumatra Provinces, the growth of domestic investment was 28.03 percent and 30.63 percent on average. 
Domestic investment's positive growth will certainly have a very significant effect on the expansion of job opportunities, increasing the population's overall income. Domestic investment activities in the 5 provinces of Southern Sumatra are based on activities to increase agricultural products' added value, especially rubber and palm oil, through agro-industry and agribusiness-based agricultural commodity processing. Besides, other economic activities that have also contributed to an increase in the flow and amount of domestic investment in 5 provinces located in Southern Sumatra are the increase in coal mining exploration in the last seven years.

To increase domestic investment flow to encourage and develop regional Economy in South Sumatra, several policies are needed related to bureaucratic and licensing arrangements and other policies related to fiscal, legislation, workforce, infrastructure, management, natural resources, and others a whole and integrated. In the last three years, the government's economic policy packages are a concrete effort to spur and increase domestic investment share both in the short and long term.

\subsection{Export Development}

The Economy in Southern Sumatra is one of the areas that is quite developed and plays an important role in encouraging international trade in the Sumatra region. The main export activity that is the mainstay of the region in 5 provinces in Southern Sumatra is the export of products derived from main agricultural products such as coconut, palm, and rubber. Agricultural products processed through agribusiness and agro-industrial activities play an important role in the Economy in Southern Sumatra, including Jambi Province, South Sumatra Province, Bengkulu Province, and Lamp and Bangka Belitung Province.

Export activities in 5 provinces in Southern Sumatra experienced a significant decline, ranging from minus 4.05 percent to minus 32.10 percent. Lampung Province experienced a decline in exports during the 2012-2016 period by minus 4.05 percent, and this figure is the smallest compared to other provinces in the southern part of Sumatra. Meanwhile, the export growth rate that experienced a sharp decline was Bengkulu Province, namely by minus 32.10 percent. Simultaneously, the other two provinces, respectively Jambi Province and South Sumatra Province, had negative growth of minus 14.80 percent and minus 19.78, respectively, percent during the 2012-2016 period.

The decline in foreign trade performance in the Southern part of Sumatra was triggered by fluctuations in the main agricultural sector prices, especially the plantation sub-sector, namely oil palm and rubber. These two types of commodities are the mainstay of earning foreign exchange and have also contributed significantly to government revenue and a positive impact on the expansion of job opportunities and business opportunities. Therefore, it is necessary to have mature policies and strategies in order to maintain the investment climate and expand exports in the context of maintaining and developing the potential of natural resources and regional economic resources in order to strengthen the basic structure of the regional economy both in the short and long term.

\subsection{Employment Structure}

In general, the economy in the Southern part of the Sumatra region still relies on the primary sector as a source of economic growth. Due to the primary sector as the mainstay sector in the Southern part of Sumatra, the primary sector remains the dominant sector in providing large enough employment opportunities, namely the utility sector, the service sector, the trade sector. It shows how important the primary sector's role is in contributing to the economy-the Sumatra region's southern part. For Jambi Province, in 2013, the primary sector absorbed 54.28 percent of the total working workforce. In 2015, this figure had increased to 54.58 percent.

Meanwhile, in South Sumatra Province, labor absorption in the primary sector was relatively stagnant, namely 56.28 percent in 2013 and 56.29 percent in 2015. In Bengkulu Province, the agricultural sector's absorption to labor increased from 53.35 percent in 2013 to 55.45 percent in 2015. In Lampung Province, there was a tendency to decrease employment in the primary sector, namely from 51.86 percent in 2013 to 49.57 percent in 2015.

\subsection{Jambi Province}

Jambi Province is one of 5 provinces in the Southern part of Sumatra. Jambi Province, Jambi's economic growth in 2015 shows that the primary sector is still the largest contributor to Jambi Province's GDP, namely 47.25 percent, followed by the services sector (tertiary) of 34, 31 percent and the secondary sector 18.44 percent. During the 2012 to 2016 period, economic growth tended to decline. In 2012 the Economy of Jambi Province grew by 7.03 percent. Then in 2013, it fell to 6.84 percent, and in 2014 it grew by 7.36 percent. In 2015 the Economy of Jambi Province grew only by 4.2 percent and in 2016 by percent. 
Judging from the workforce structure, the primary sector (agriculture and mining) is still the dominant sector in employment. The primary sector's contribution in absorbing labor reached 46.40 percent, the industrial sector by 10.9 percent. The trade sector absorbs labor by 11.5 percent, and the construction sector absorbs the workforce by 7.7 percent and the other sectors by 24.1 percent (see Figure 1).
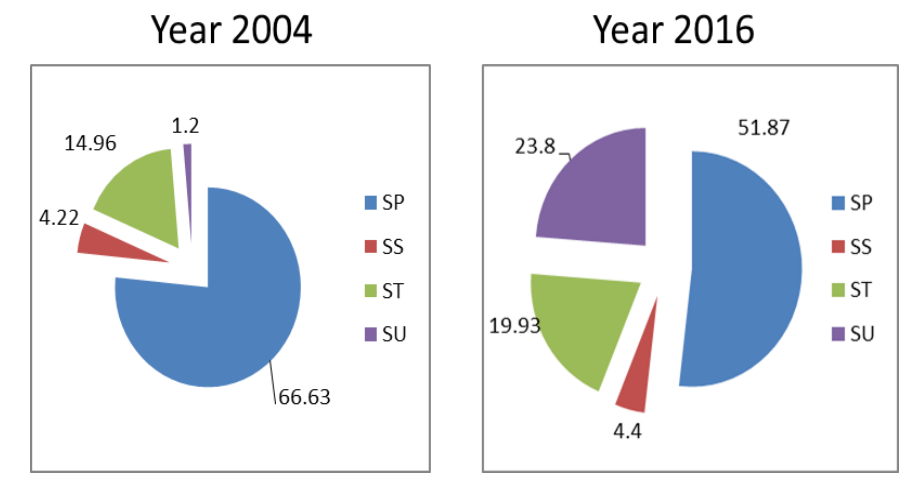

Figure 1 Workforce Structure in Jambi Province 2004 and 2016 Source: Processed from BPS data $[17,18]$

Based on Figure 2, it can be seen that the transformation of the labor structure in Jambi Province has relatively never occurred. The primary sector does show a downward trend in employment, but it is relatively very slow. Likewise, the absorption of labor in the secondary sector, tertiary sector, and the utility sector has not experienced significant changes. Although there was an increase in labor absorption in the secondary sector (industry), the tertiary sector, and the utility sector, the increase was relatively low.

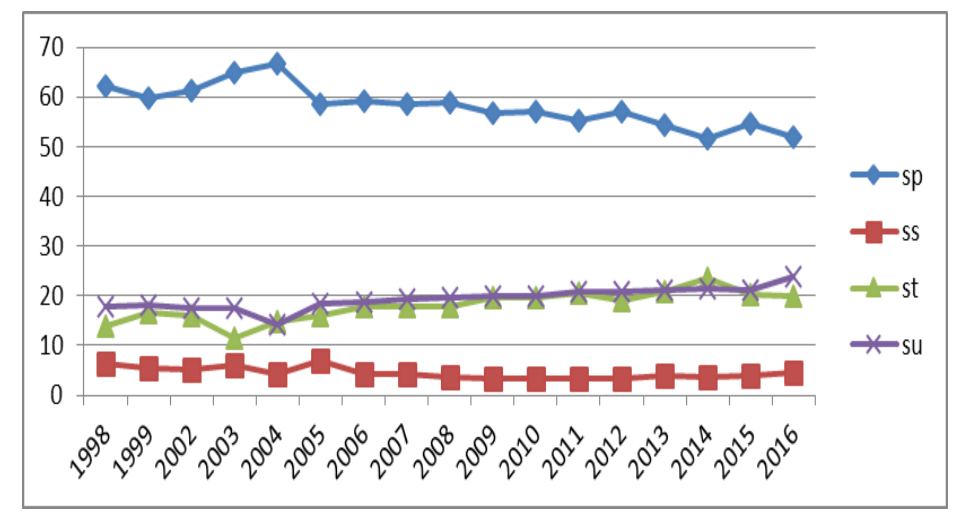

Graph 2 The pattern of Workforce Structure in Jambi Province 1998 - 2016 Source: Processed from BPS $[17,18]$

\subsection{South Sumatera Province}

South Sumatra Province is a province included in the large category compared to other provinces in Southern Sumatra. The economic growth of South Sumatra Province during the last four years has an average of 4.91 percent. In 2013 the Economy of South Sumatra grew by 5.31 percent. In 2014 the Economy of South Sumatra grew by 4.70 percent. Then in 2015, the economic growth of South Sumatra grew by 4.50 percent and in 2016 by 5.11 percent.

Based on the production structure, the primary sector still dominates South Sumatra's economy, with a contribution reaching 35.95 percent. The second-largest contribution to the GRDP of South Sumatra is the tertiary sector, with 29.47 percent. The third place is the industrial sector with a contribution of 18.86 percent. Furthermore, the utility sector contributed 15.72 percent to the GRDP of South Sumatra.

Judging from the production structure, the industrial sector in South Sumatra has contributed 18.86 percent to GRDP. However, in terms of employment, it turns out that the industrial sector's contribution in South Sumatra can only absorb about 5 percent of the workforce and is the lowest sector in employment. The primary sector dominates the structure of the workforce in South Sumatra. The second sector that contributes significantly to absorbing labor is the utility sector (see Figure 2). 
a. Year 2004

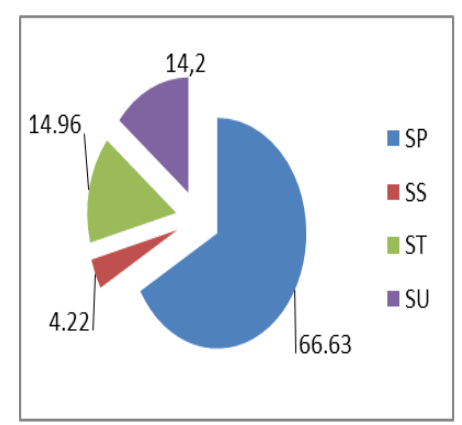

b. Year2016

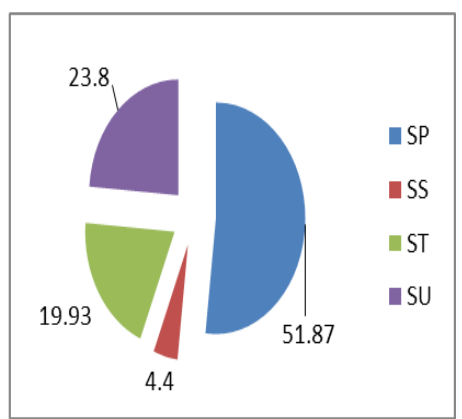

Figure 2 South Sumatra Province Workforce Structure 2004 \& 2016 Source: BPS Data $[17,18]$

From Figure 2 above, it can be seen that the primary sector still dominates the absorption of labor in South Sumatra. In 2004, the primary sector absorbed labor by 66.63 percent, and 14 years later, in 2016, the absorption capacity decreased to 51.87 percent. The decline in the primary sector's absorption capacity shifted to the utility sector and the tertiary sector. The utility sector increased its absorption of labor from 14.2 percent in 2004 to 23.8 percent in 2016. Meanwhile, the industrial sector of labor absorption remained relatively unchanged from 4.22 percent in 2004 to 4.4 percent in 2016. The pattern of changes in labor absorption is shown in Graph 3 below.

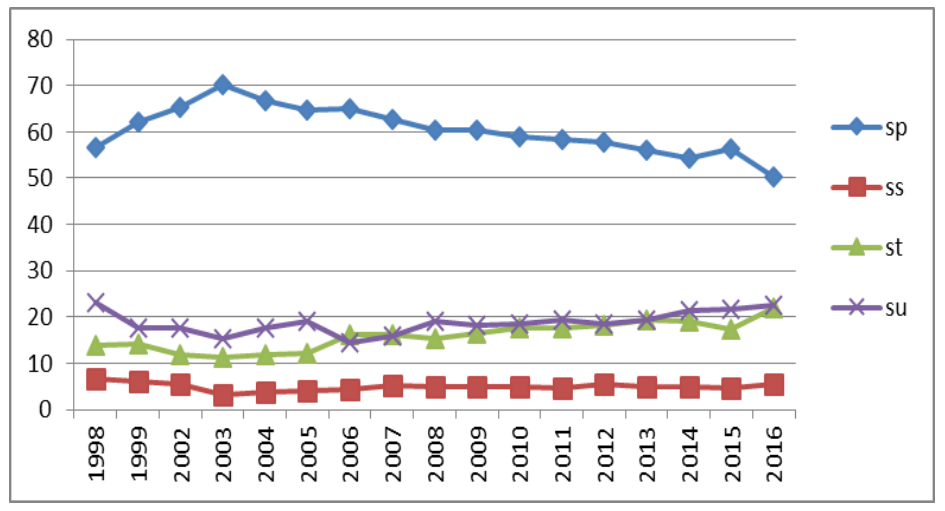

Graph 3 Patterns of Change in Workforce Structure in South Sumatra Province Years 1998 - 2016 Source: BPS data processing $[17,18]$

\subsection{Bengkulu Province}

Bengkulu Province's Economy in 2016 grew by 5.30 percent, an increase compared to 2015, which grew by 5.13 percent. The highest growth was achieved from the production side by the electricity and gas supply business sector at 17.8 percent and accommodation and food and drink by 9.67 percent. Meanwhile, the highest growth was achieved from the expenditure side by the export component of goods and services at 7.21 percent (BPS).

The economic structure of Bengkulu Province in 2016 was still dominated by agricultural business fields by 28.82 percent, wholesale and retail trade by 14.91 percent, and government administration by 8.77 percent. Meanwhile, from the expenditure side, it was still dominated by the components of household consumption expenditure and imports of goods and services amounting to 65.85 percent and 65.59 percent, respectively.

In terms of employment, agriculture and mining (primary) are still the dominant sectors. In 2004 the primary sector was able to absorb a workforce of 68.75 percent, and the industrial sector was only able to absorb a workforce of 1.69 percent. In 2016 the primary sector still dominated in the absorption of labor, namely 44.26 percent. The second place that can absorb a greater workforce is the tertiary sector at 25.9 percent, and the third place is the utility sector at 24.64 percent. Although the industrial sector is the lowest in employment, it shows a significant increase in absorbing labor. If in 2004 it was only able to absorb a workforce of 1.69 percent, then in 2016, it could absorb a workforce of 5.2 percent of the total workforce working in Bengkulu Province. The pattern of changes in the workforce structure in Bengkulu Province is shown in Figure 3 below. 

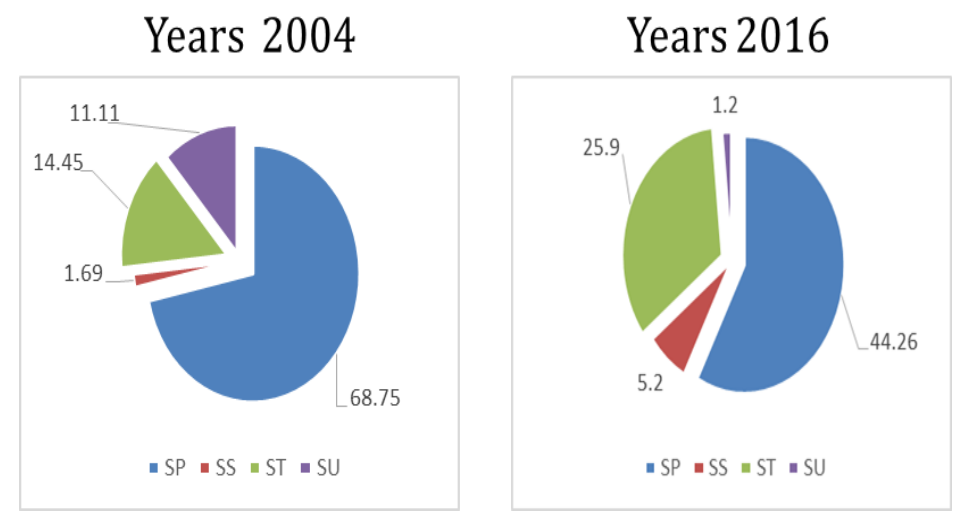

Figure 3 Changes in the Workforce Structure in Bengkulu Province 2004 - 2016 Source; BPS, Data Processing $[17,18]$

Based on the data in Figure 3 above, it can be seen that there has been a shift in labor from the primary sector, which in 2004 amounted to 68.75 percent to only 44.26 percent and shifted to the tertiary sector from 14.45 percent to 25.9 percent and the utility sector by 11.11 percent to 24.64 percent. The industrial sector has not given any significant meaning even though there has been an increase from 1.69 percent to 5.20 percent. The pattern of change in labor absorption in Bengkulu Province can be described as in Graph 4 below.

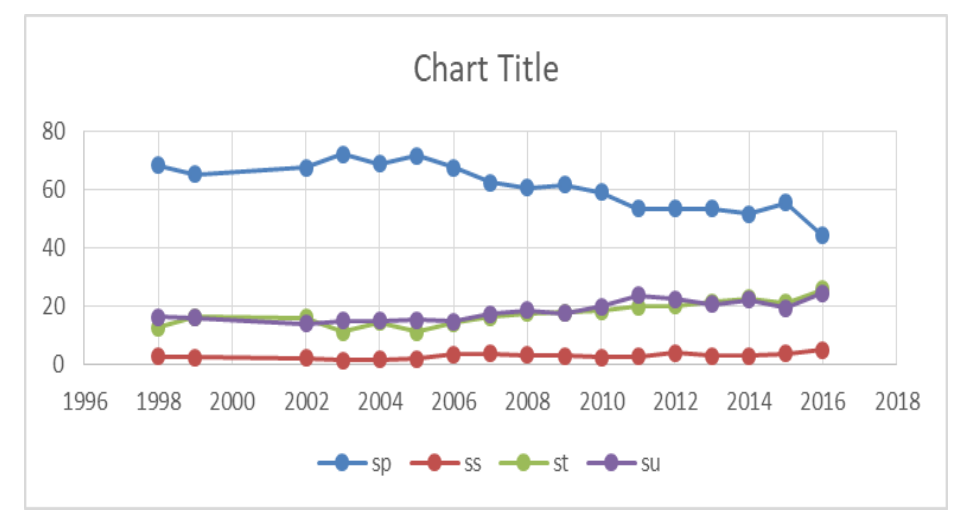

Graph 4 Patterns of Change in Workforce Structure in Bengkulu Province Years 1998 - 2016 Source: BPS, Data Processing $[17,18]$

\subsection{Lampung province}

In the economy of Lampung Province in early 2016, the Economy of Lampung grew 5.05 percent compared to 2015. All business fields support increased economic growth in Lampung Province. The three business fields with the highest growth were Electricity and Gas Procurement, which grew by 25.56 percent, followed by the construction sector at 19.07 percent, and Information and Communication at 11.28 percent (BPS 2016). The economic structure of Lampung Province is still dominated by three fields Main businesses, namely: the primary sector (agriculture, forestry, and fisheries), which contributed 39.90 percent, the secondary sector (processing industry) with a contribution of 17.81 percent, and the utility sector (wholesale-retail trade and car-motorcycle repair) with a contribution of 10.72 percent.

Similar to the production structure, employment in Lampung Province is still dominated by the primary sector. In 2004 the primary sector absorbed labor reached 67.13 percent, the secondary sector was 4.81 percent, the tertiary sector 11.11 percent, and the utility sector 16.95 percent. In 2016 the absorption of labor in Lampung Province experienced changes, especially in the primary sector, from 67.13 percent (2004) to 48.72 percent (2016). These changes are visually seen as in Figure 4

Furthermore, the pattern of changes in the workforce in Lampung Province is seen in the graph, which has not experienced significant changes. 

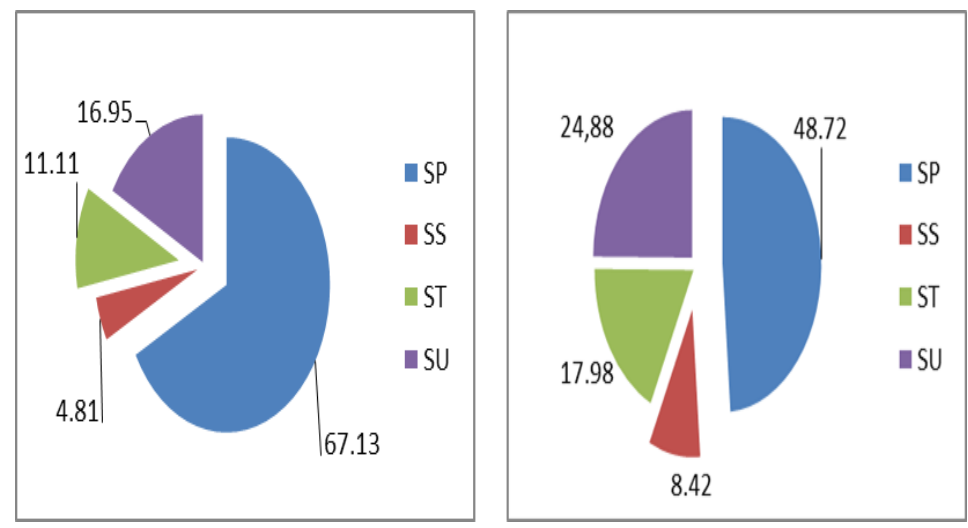

Figure 4 Workforce Structure in Lampung Province in 2004 and 2016 Source: BPS, Data Processing $[17,18]$

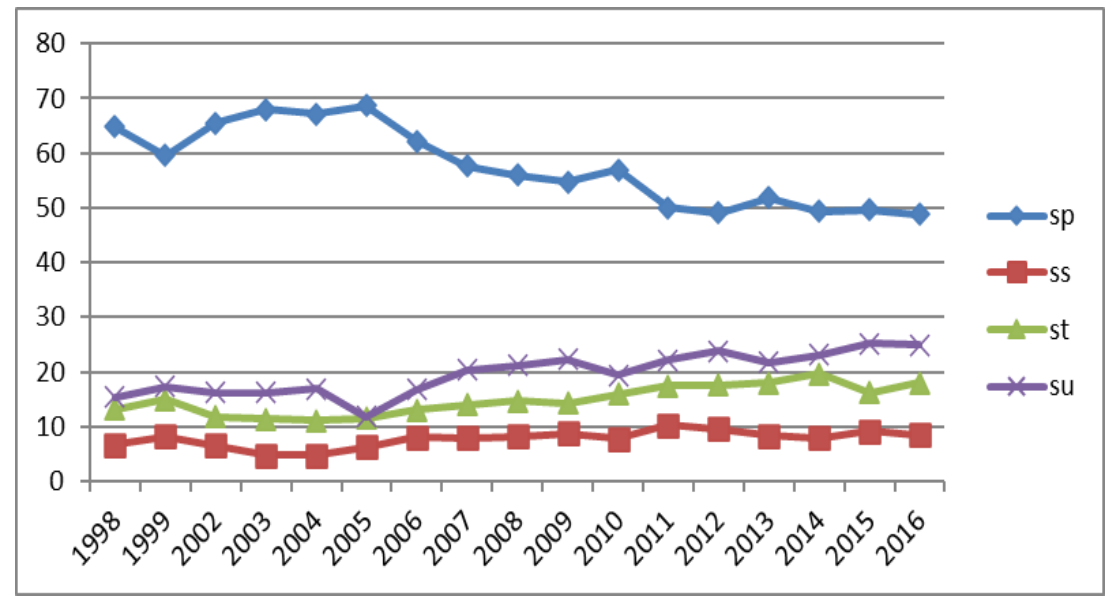

Graph 5 Patterns of Change in Labor Structure in Lampung Province Source: BPS, Data Processing $[17,18]$

However, when viewed from the graph, it is illustrated that the absorption of labor by the primary sector shows a downward trend, from 67.13 percent to 48.72 percent. The decline in labor absorption by the primary sector was followed by an increase in employment by the utility and tertiary sectors. Meanwhile, the secondary sector has remained relatively unchanged.

\subsection{Bangka Belitung Province}

The Economy of Bangka Belitung Province in 2016 grew by 3.83 percent, an increase compared to 2015, which amounted to 3.68 percent. Economic growth in Bangka Belitung Province is driven by increased investment and exports as well as slowing imports. The increase in Bangka Belitung Province's economic growth originated from the processing industry's growth and mining and quarrying business fields. From the expenditure side, the share of economic growth comes from the household consumption and investment components.

Bangka Belitung Province's economic structure is dominated by the primary sector with a contribution of 32.17 percent. After the primary sector, the second-largest contributor to the formation of GRDP is the tertiary sector, with a contribution of 26.11 percent. The secondary sector (processing industry) contributed 19.98 percent.

In terms of employment, the primary sector is still a mainstay for Bangka Belitung Province. The absorption of labor by the primary sector reached 62.51 percent in 2004 . The second place was the utility sector, with an absorption capacity of 19.67 percent. The sector with the lowest absorption of labor was the manufacturing sector at 3.46 percent. 
In 2016 the absorption of labor in the primary sector decreased to 43.61 percent. The decline in the primary sector's absorption capacity shifted to the utility sector, which increased to 25.80 percent, and the tertiary sector by 22.57 percent. The secondary sector increased from 3.46 percent in 2004 to 8.02 percent in 2016. This increase is significant but has not meant much in changing the employment structure in Bangka Belitung Province. The workforce structure in Bangka Belitung Province is illustrated in Figure 5.
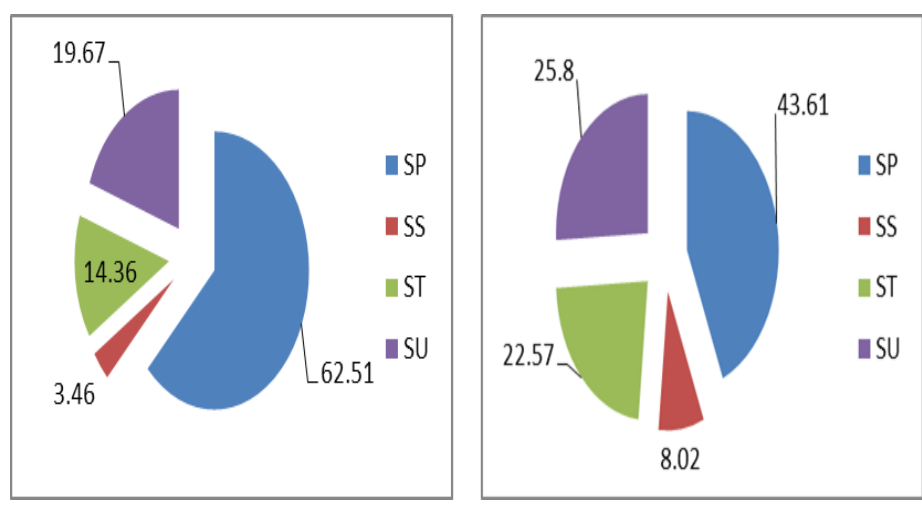

Figure 5 Workforce Structure in Bangka Belitung Province 2004 and 2016 Source: BPS Data Processing $[17,18]$

Furthermore, the pattern of changes in Bangka Belitung Province's workforce structure is graphically shown in Graph 6.

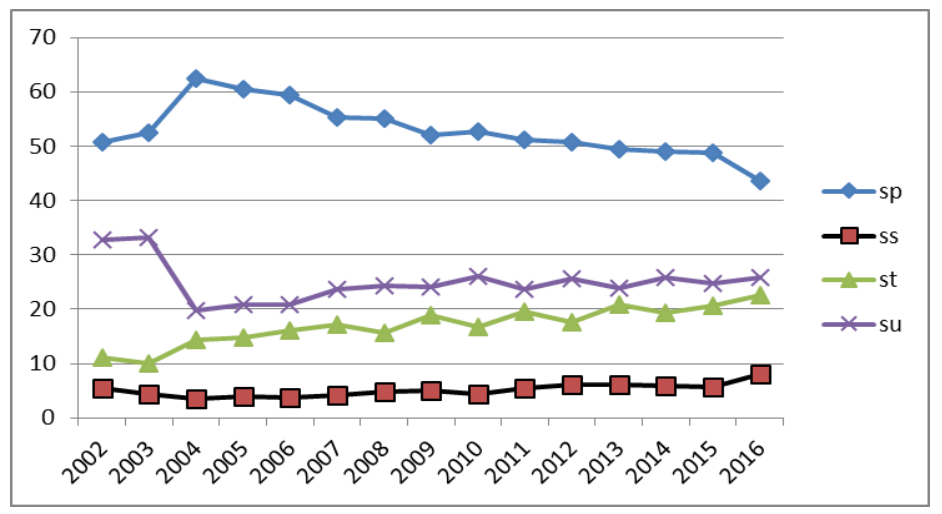

Graph 6 Patterns of Change in Workforce Structure in Bangka Belitung Province 2002 - 2016 Source: BPS Data Processing. $[17,18]$

\subsection{Econometrica Analysis of Changes in the Structure of the Workforce}

Based on data from 5 provinces in the Southern part of Sumatra, the results of an economic analysis that affect changes in the structure of the workforce are as follows:

$$
\begin{aligned}
Y= & 600852.6+0.000649 \mathrm{X} 1+15.97853 \mathrm{X} 2 \\
& (4.152613)(11,58900) \quad(5,699879) \\
& F=113.8175
\end{aligned}
$$

From the results of this analysis and statistically, both the model (F test) and the variable were very significant. These results explain that although changes in the workforce structure in the provinces in Southern Sumatra have not led to a transformation of the labor structure, the changes that have occurred are influenced by exports and domestic investment. Of the two variables, the increase in exports is one thousand dollars (Rp.13,500,000). The workforce who works will increase by 659 people, whereas if domestic investment increases by 1 (one) percent, the absorption of labor in Southern Sumatra will increase by 16 people. 
In this study, the Random Effect Model (REM) was chosen. After being tested using the Hausman test, the REM model has a probability value of 0.1702 , which means it is greater than alpha 5 percent or 0.05 . The econometric analysis process's complete results in this study can be seen in this research report's attachment section. In terms of panel data per province, the results of the econometric analysis by producing panel data regression equations for each province are as follows:

\subsubsection{Jambi}

The panel data regression model that is formed is:

Tkerja $=645,481.62+0.00742$ exports $+261,900$ pmdn (significant at alpha 0.05 . It means every 1 percent increase in exports, employment opportunities will increase by 0.00742 percent, and with every 1 percent increase in domestic investment occurs, available work increased by 261.9 people.

\subsubsection{South Sumatra}

The regression model for which panel data is formed is:

Tkerja $=657,614.78+0.007242$ exports $+261,900$ pmdn (significant at alpha 0.05 ). It means: every time there is an increase in exports by 1 percent, employment opportunities will increase by 0.00742 percent, and every time there is an increase in domestic investment by 1 percent, employment opportunities will increase by 261.9 people.

\subsubsection{Bengkulu}

The panel data regression model that is formed is:

Tkerja $=679,493.31+0.007242$ exports $+261,900$ pmdn (significant at alpha 0.05 ). It means every time there is an increase in exports by 1 percent, employment opportunities will increase by 0.00742 percent, and every time there is an increase in domestic investment by 1 percent, employment opportunities will increase by 261.9 people.

\subsubsection{Lampung}

The panel data regression model formed by:

Tkerja $=686,422.68+0.007242$ exports $+261,900$ pmdn (significant at alpha 0.05 ). It means every time there is an increase in exports by 1 percent, employment opportunities will increase by 0.00742 percent, and every time there is an increase in domestic investment by 1 percent, employment opportunities will increase by 261.9 people.

The analysis results above show that employment opportunities in 5 provinces in Southern Sumatra are influenced by domestic investment. At the same time, exports still make a positive contribution even though the figure is relatively small.

\section{Conclusion}

Based on the result and discussion, the research found several conclusions as follows: The primary sector still dominates the workforce structure in the provinces in the Southern Sumatra region. In contrast, the secondary industry has not played many roles in the absorption of labor. Despite a change in the labor structure, employment transformation in the Southern Sumatra region's provinces has not yet occurred. Although the workforce's shift has not yet occurred, changes in the Southern Sumatra region's workforce structure were strongly influenced by exports and domestic investment.

From the previous discussion results, several things are suggested. It is necessary to formulate and enact policies for restructuring and non-bureaucratic at the regional level to accelerate regional economic development. A strategy for processing agricultural products is needed so that their export value can increase and can make a more significant contribution to the economy of the Southern part of Sumatra

In the analysis of the transformation of labor and employment opportunities in the southern part of Sumatra, the policy orientation of expanding employment opportunities keep related to at least two main macroeconomic aggregate variables, namely exports and domestic investment. Therefore it is essential to formulate a spatial policy to encourage exports and encourage domestic investment intensity through restructuring and non-bureaucratization policies in 5 provinces in the Southern Sumatra region comprehensively and sustainably 


\section{Compliance with ethical standards}

\section{Acknowledgments}

This study's financial support was provided by a grant from the Faculty of Economics and Business, Universitas Jambi, in 2017.

\section{Disclosure of conflict of interest}

The authors declare that there is no conflict of interest

\section{References}

[1] Timmer P. The Mathematics of Structural Transformation. West Central Africa Office. Thematic Research Note. 2012.

[2] Chenery H, Syrquin M, Elkington H. Pattern of Development, 1950-1970. New York Oxford University Press. 1975.

[3] Pieper U. Sectoral regularities of productivity growth in developing countries: A Kaldorian interpretation. Cambridge Journal of Economics. 2003; 27(6): 831-850.

[4] Adelman I. Fallacies in Development Theory and Their Implications for Policy. In Frontiers of Development Economics: The Future in Perspective, ed. Meier, Gerald M., and Joseph E. Stiglitz. World Bank, New York. 2001.

[5] Hardiwan D, Amir A, Junaidi J, Delis A. The linkages and impact of plantation-based sectors on economy and poverty in Jambi province, Indonesia: Miyazawa's input-output model. Agricultural and Resource Economics: International Scientific E-Journal. 2019; 5: 5 - 19.

[6] Goel M, Restrepo-Echavaria P. India's Atypical Structural Transformation. Economic Synopses. 2015; 23:1-2

[7] Tambunan TH. Perekonomian Indonesia Era Orde Lama Hingga Jokowi. Jakarta: Penerbit Ghalia Indonesia. 2015.

[8] Anwar et al. Widjojo Nitisastro 70 Tahun. Pembangunan Nasional: Teori, Kebijakan dan Pelaksanaan. Fakultas Ekonomi Universitas Indonesia, Jakarta. 1997.

[9] Djojohadikusumo S. Perkembangan Pemikiran Ekonomi Dasar Teori Ekonomi Pertumbuhan dan Ekonomi Pembangunan. Jakarta: LP3ES. 1994.

[10] Ferede T. Sectoral Economic Growth and Structural Transformation in Ethiopia. Department of Economics Addis Ababa University. 2015.

[11] Fauzi A, Amir A, Junaidi J, Hidayat S. Change of Economic Structure in Jambi Province: Input-Output Model Approach. Scientific Research Journal (SCIRJ). 2019; 7(8): 62-72.

[12] Amir A. Pembangunan dan Kualitas Pertumbuhan Ekonomi Dalam Era Globalisasi (Teori, Masalah dan Kebijakan). Bogor: Penerbit Biografika. 2007.

[13] Mecik O, Afsar M. The Effects of Structural Transformations in Economy on Labor Markets: the Case of OECD Countries. International Journal of Business and Social Science. 2014; 5(9): 230-237.

[14] Afzal M. Do Structural Transformation and Trade Liberalization Cause Economic Growth in Pakistan?. Applied Econometrics and International Development. 2012; 12(1).

[15] World Bank. Indonesian Economic Transformation Policy Input for an Indonesian Jobs Strategy. 2016.

[16] Behera DK, Tiwari M. Structural Transformation in India: an Economteric Investigation. Ministry of Home Affairs Government of India, New Delhi. 2011.

[17] BPS. Statistik Indonesia. Jakarta: Badan Pusat Statistik. 2016.

[18] BPS. Keadaan Angkatan Kerja di Indonesia Agustus 2016. Jakarta: Badan Pusat Statistik. 2016. 